\title{
YIELD PERFORMANCE OF UPLAND RICE CULTIVARS AT DIFFERENT RATES AND TIMES OF NITROGEN APPLICATION $^{(1)}$
}

\author{
José Hildernando Bezerra Barreto( ${ }^{(2)}$, Ismail Soares ${ }^{(3)}$, José \\ Almeida Pereira ${ }^{(4)}$, Antonio Marcos Esmeraldo Bezerra ${ }^{(5)}$ \& José \\ Aridiano Lima de Deus ${ }^{(6)}$
}

\begin{abstract}
SUMMARY
Nitrogen is the most important nutrient for rice (Oryza sativa L) yields. This study aimed to evaluate the response of upland rice cultivars to $\mathrm{N}$ rate and application times in a randomized block design, in subdivided plots with four replications. The studied factors were five rice cultivars (BRS MG Curinga, BRS Monarca, BRS Pepita, BRS Primavera, and BRS Sertaneja), three application times (100\% at planting, $50 \%$ at planting - $50 \%$ at tillering and $100 \%$ at tillering) and four $\mathrm{N}$ rates $\left(0,50,100\right.$, and $\left.150 \mathrm{~kg} \mathrm{ha}^{-1}\right)$. All cultivars responded to increased rates and different times of $\mathrm{N}$ application, especially BRS Primavera and BRS Sertaneja, which were the most productive when $50 \% \mathrm{~N}$ rates were applied at sowing and $50 \%$ at tillering. The response of cultivar BRS Monarca to $\mathrm{N}$ fertilization was best when $100 \%$ of the fertilizer was applied at tillering.

Index terms: Oryza sativa $\mathrm{L}$, nitrogen fertilization, production components.
\end{abstract}

(1) Part of Monograph the first author, presented the course in Agronomy, Federal University of Ceará - UFC. Received for publication in May 4, 2011 and approved in January 24, 2012.

(2) Agronomist, Federal University of Ceará - UFC. Post Office Box 12168, CEP 60356-000 Fortaleza (CE). E-mail: jhbbarreto@ yahoo.com.br

(3) Associate Professor of Soil Science Department, UFC. E-mail: ismail@ufc.br

(4) Researcher of EMBRAPA - Agricultural Center of the Mid-North. Post Office Box 01, CEP 64006-220 Teresina (PI). E-mail: almeida@cpamn.embrapa.br

(5) Associate Professor of Plant Science Department, UFC. E-mail: esmeraldo@ufc.br

(6) Master student in Agronomics - Soils and Plant Nutrition, UFC. E-mail: aridianolima@yahoo.com.br 


\title{
RESUMO: DESEMPENHO PRODUTIVO DE CULTIVARES DE ARROZ DE TERRAS ALTAS COM DIFERENTES DOSES E ÉPOCAS DE APLICAÇÃO DE NITROGÊENIO
}

\begin{abstract}
O N é o nutriente de maior importância para a produtividade do arroz (Oryza sativa L.). Este trabalho teve por objetivo avaliar a resposta de cultivares de arroz de terras altas em função de diferentes doses e épocas de adubação nitrogenada. Utilizou-se o delineamento experimental em blocos casualizados com parcelas subsubdivididas, com quatro repetições. Foram estudadas cinco cultivares de arroz (BRS MG Curinga, BRS Monarca, BRS Pepita, BRS Primavera e BRS Sertaneja), três épocas de aplicação de N (100\% na semeadura; $50 \%$ na semeadura e $50 \%$ no perfilhamento; e $100 \%$ no perfilhamento) e quatro doses de $N\left(0,50,100\right.$ e $\left.150 \mathrm{~kg} \mathrm{ha}^{-1}\right)$. As cultivares avaliadas responderam ao incremento de doses e à época de aplicação de $N$, destacando-se BRS Primavera e BRS Sertaneja como as mais produtivas quando as doses de $N$ foram distribuidas $50 \%$ na semeadura e $50 \%$ no perfilhamento, enquanto a cultivar BRS Monarca apresentou a melhor resposta à adubação nitrogenada quando todo o $N$ foi aplicado no perfilhamento.
\end{abstract}

Termos de indexação: Oryza sativa L., adubação nitrogenada, componentes de produção.

\section{INTRODUCTION}

In Brazil, rice is one of the major annual crops of considerable importance, being grown in all regions in various environments. In Ceará, rice is mostly grown in flood-irrigated lowland soils and in upland areas that are waterlogged in the rainy season, and only a small economically unrepresentative portion is grown in moist uplands in the highlands of the State.

For rice cultivation some factors should be considered essential to increase yield and economic profitability. The selection of genotypes with high $\mathrm{N}$ use efficiency is considered one of the best ways to reduce crop production costs (Fageria \& Barbosa Filho, 1982). The greater response to this nutrient of genotypes with different nutritional requirements and tolerance to nutritional stress (Brown \& Jones, 1997) may increase yields (Andrade et al., 1992).

Nitrogen is responsible for an increased leaf area, which raises the efficiency of solar radiation interception, photosynthetic and metabolic rate and, consequently, grain yield (Fageria \& Santos, 2010). The absence of $\mathrm{N}$ in the vegetative phase reduces the number of panicles, since this nutrient stimulates tillering (Mauad et al., 2003).

In studies on rice response to $\mathrm{N}$ - fertilization rates and timing, Cornélio et al. (2007) found lower grain yield when all $\mathrm{N}$ was applied at planting. For upland rice, concentrated $\mathrm{N}$ applications near the stage of panicle initiation were most efficient, favoring a greater crop yield, since two yield components are defined in the reproductive phase the number of spikelets per panicle and grain weight (Marzari, 2005).
According to Fageria et al. (2003), the use of different cultivars, $\mathrm{N}$ rates, sources and application times can significantly increase the efficiency of $\mathrm{N}$ fertilizers and, consequently, the yield of annual crops such as rice. If rates and timing of $\mathrm{N}$ application are inadequate, yields are reduced and the incidence of diseases increases (Fageria, 1997), e.g., of rice blast (Pyricularia grisea), a disease causing spikelet sterility (Prabhu et al., 1986; Guimarães \& Prabhu, 2002).

This study aimed to evaluate the response of upland rice cultivars to different $\mathrm{N}$ rates and application times.

\section{MATERIALS AND METHODS}

The experiment was conducted in Iguatu, in the South Central region of the State of Ceará-Brazil (39॰16' 10.07' W, 6 ${ }^{\circ} 17^{\prime} 13.61^{\prime}$ ' S, $213 \mathrm{~m}$ asl), from February to June 2009. The climate is BSw'h' (hot tropical semi-arid), according to the classification of Köeppen. The average air temperature is $27^{\circ} \mathrm{C}$, with a minimum of $20^{\circ} \mathrm{C}$ in the coldest month (July) and a maximum of $35^{\circ} \mathrm{C}$ in the hottest month (November), with average annual rainfall of $800 \mathrm{~mm}$ (Figure 1).

The soil of the experimental area was classified as Vertisol (Embrapa, 2006). In the 0-0.20 m layer, the texture was silty clay and particle size (in $\mathrm{g} \mathrm{kg}^{-1}$ ) analyzed as: coarse sand 36, fine sand 128, silt 440, and clay 396 (pipette method), with the following chemical properties (in $\mathrm{cmol}_{\mathrm{c}} \mathrm{kg}^{-1}$ ): $\mathrm{Ca}^{2+} 28.30$; $\mathrm{Mg}^{2+} 1.80$ and $\mathrm{Al}^{3+}\left(\mathrm{KCl} 1 \mathrm{~mol} \mathrm{~L}^{-1}\right) 0.05 ; \mathrm{H}+\mathrm{Al}$ $0.83\left(\mathrm{Ca}(\mathrm{OAc})_{2} 0.5 \mathrm{~mol} \mathrm{~L}^{-1}\right) ; \mathrm{Na}^{+} 0.31$ and $\mathrm{K}^{+} 0.46$ 


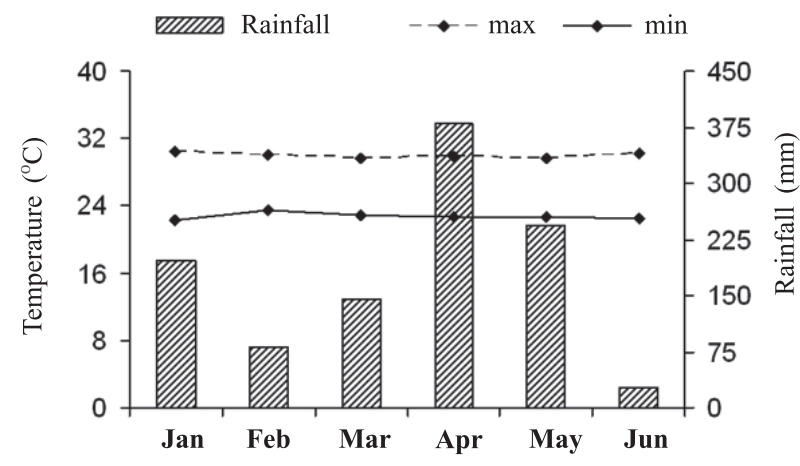

Figure 1. Temperature and rainfall during the experiment.

(Mehlich-1); pH in water 7.4 (relationship 1:2.5); $11.79 \mathrm{~g} \mathrm{~kg}^{-1}$ organic matter (Walkley Black) and $12 \mathrm{mg} \mathrm{kg}^{-1} \mathrm{P}$ (Mehlich-1), according to the method of Embrapa (1997).

The treatments consisted of five upland rice cultivars (BRS MG Curinga, BRS Monarca, BRS Pepita, BRS Primavera, and BRS Sertaneja), three $\mathrm{N}$ application times (100\% at sowing; $50 \%$ at sowing - $50 \%$ at tillering and $100 \%$ at tillering) and four $\mathrm{N}$ rates $\left(0,50,100\right.$, and $\left.150 \mathrm{~kg} \mathrm{ha}^{-1}\right)$. The experiment was arranged in a randomized block design in subdivided plots, with four replications. The cultivars were the main plots, and application times and $\mathrm{N}$ rates represented the sub-plots. The sub-subplots consisted of five $6.0 \mathrm{~m}$ rows, spaced $0.35 \mathrm{~m}$ apart, with evaluation of the three central rows, eliminating $0.5 \mathrm{~m}$ at the ends. The soil was conventionally tilled by disking twice. Rice was sown by hand, distributing seeds in furrows, at an average density of 80 seeds per meter.

The 100 and $50 \% \mathrm{~N}$ rate at sowing was applied in the sowing furrow $0.05 \mathrm{~m}$ below the seeds and the 100 and $50 \% \mathrm{~N}$ rates at tillering beside the plant rows. Ammonium sulphate was as used as $\mathrm{N}$ source. Weeds were controlled by hand hoeing.

Because of the different cycles, the cultivars were hand harvested on three dates (95, 105 and 115 days after emergence), when an average of $90 \%$ of panicles had grains with typical mature coloration. Plants were cut $0.10 \mathrm{~m}$ above the soil surface and left in the sun for six hours. After that the grains were removed from panicles in a handmade wooden mill.

The following yield parameters were evaluated: a) Number of panicles per $\mathrm{m}^{2}$ - Count of panicles per meter in one row of the evaluated area and extrapolated to square meters; b) Panicle length distance from the panicle base to the spikelet base; c) Number of filled grains per panicle - Count of full spikelets after seed shattering; d) Number of sterile spikelets per panicle - Count of sterile spikelets, expressed in percentage of the total number of spikelets per panicle; e) Mass of thousand grains calculated from $100 \mathrm{~g}$ weight after grain drying and moisture correction to $13 \%$ in four samples of each sub-subplot; f) Grain yield - yield per sub-subplot.

The grain yield and yield components were subjected to analysis of variance. The averages of the factors cultivar and $\mathrm{N}$ application time were subjected to the Tukey test at $5 \%$, and the effect of $\mathrm{N}$ rates was assessed by regression analysis.

Table 1. Values of $\mathrm{F}$ calculated from the analysis of variance for number of panicles per $\mathrm{m}^{2}(\mathrm{NP})$, panicle length (PL), number of filled grains per panicle (NFGP), percentage of sterile spikelets per panicle (SS), 1000-grain mass (ThM) and grain yield (yield)

\begin{tabular}{|c|c|c|c|c|c|c|c|}
\hline SV & DF & NP & PL & NFGP & SS & ThM & Yield \\
\hline Block & 3 & $0.32^{\mathrm{ns}}$ & $1.64^{\mathrm{ns}}$ & $0.97^{\mathrm{ns}}$ & $0.11^{\mathrm{ns}}$ & $1.56^{\mathrm{ns}}$ & $483.53^{* *}$ \\
\hline Cultivars (C) & 4 & $1.67^{\mathrm{ns}}$ & $43.54^{* *}$ & $12.49^{* *}$ & $1.76^{\mathrm{ns}}$ & $30.10^{* *}$ & $5.63^{*}$ \\
\hline Error a & 12 & - & - & - & - & - & - \\
\hline Time (T) & 2 & $2.88^{\mathrm{ns}}$ & $2.03^{\mathrm{ns}}$ & $3.72^{*}$ & $5.43 * *$ & $0.64^{\mathrm{ns}}$ & $47.86^{* *}$ \\
\hline $\mathrm{C} * \mathrm{E}$ & 8 & $2.18^{\mathrm{ns}}$ & $1.06^{\mathrm{ns}}$ & $1.54^{\mathrm{ns}}$ & $2.22^{\mathrm{ns}}$ & $0.61^{\mathrm{ns}}$ & $64.73^{* *}$ \\
\hline Error b & 30 & - & - & - & - & - & - \\
\hline $\mathrm{N}$ rates $(\mathrm{D})$ & 3 & $151.02^{* *}$ & $127.90 * *$ & $53.76^{* *}$ & $11.68^{* *}$ & $0.70^{\mathrm{ns}}$ & $1,956.57^{* *}$ \\
\hline$C * D$ & 12 & $1.24^{\mathrm{ns}}$ & $4.87^{* *}$ & $2.84^{* *}$ & $2.37 * *$ & $0.42^{\mathrm{ns}}$ & $56.60^{* *}$ \\
\hline $\mathrm{T} * \mathrm{D}$ & 6 & $2.18^{*}$ & $1.98^{\mathrm{ns}}$ & $0.69^{\mathrm{ns}}$ & $0.74^{\mathrm{ns}}$ & $0.46^{\mathrm{ns}}$ & $30.86^{* *}$ \\
\hline $\mathrm{C}^{*} \mathrm{~T}^{*} \mathrm{D}$ & 24 & $2.25^{* *}$ & $2.23^{* *}$ & $0.74^{\mathrm{ns}}$ & $1.35^{\mathrm{ns}}$ & $1.35^{\mathrm{ns}}$ & $22.49^{* *}$ \\
\hline Error c & 135 & - & - & - & - & - & - \\
\hline $\mathrm{CV}$ a $(\%)$ & - & 13.26 & 6.16 & 28.07 & 63.81 & 6.19 & 8.86 \\
\hline CV b (\%) & - & 8.51 & 6.21 & 17.12 & 30.69 & 3.84 & 8.79 \\
\hline CV c $(\%)$ & - & 7.55 & 4.25 & 12.93 & 20.75 & 3.41 & 6.29 \\
\hline Overall average & - & 213.10 & 24.06 & 120.58 & 20.47 & 26.76 & $2,138.78$ \\
\hline
\end{tabular}

${ }^{\mathrm{ns}}$ not significant by the $\mathrm{F}$ test, ${ }^{*}$ and ${ }^{* *}$ Significat at 1 and $5 \%$ by the $\mathrm{F}$ test. 


\section{RESULTS AND DISCUSSION}

The effect of the interaction between cultivars, rates, and $\mathrm{N}$ application time with number of panicles per $\mathrm{m}^{2}$ was significant (Table 1). For the $100 \% \mathrm{~N}$ rate applied at planting, the regression study showed a linear effect for BRS Monarca, BRS Pepita and BRS Primavera and a quadratic effect for BRS MG Curinga and BRS Sertaneja (Figure 2a). The results confirmed that, by applying all $\mathrm{N}$ at planting, increasing $\mathrm{N}$ rates increased the number of panicles per $\mathrm{m}^{2}$. This can be attributed to the effect of $\mathrm{N}$ to increase the number of rice tillers, as also observed by Mauad et al. (2003).

When applying $50 \%$ of $\mathrm{N}$ at sowing and $50 \%$ at tillering, regression analysis showed that the number of panicles per $\mathrm{m}^{2}$ of the cultivars BRS MG Curinga, BRS Primavera and BRS Sertaneja responded linearly to increasing $\mathrm{N}$ rates (Figure 2B), increasing from 180, 185 and 174 panicles per $\mathrm{m}^{2}$, in the treatment without $\mathrm{N}$, to 251,233 and 264 panicles per $\mathrm{m}^{2}$, in the treatment $150 \mathrm{~kg} \mathrm{ha}^{-1}$ $\mathrm{N}$, respectively. Cultivars BRS Monarca and BRS Pepita adjusted quadratically to $\mathrm{N}$ rates, producing 251 and 225 panicles per $\mathrm{m}^{2}$, at 133 and $119 \mathrm{~kg} \mathrm{ha}^{-1} \mathrm{~N}$, respectively. Farinelli et al. (2004) reported that an increase in $\mathrm{N}$ fertilization promotes a significant increase in the number of panicles per $\mathrm{m}^{2}$ in upland rice.

When $100 \%$ of $\mathrm{N}$ fertilization was applied at tillering (Figure 2c), the number of panicles per $\mathrm{m}^{2}$ increased linearly with $\mathrm{N}$ rates, at rates of $0.29 ; 0.33$; $0.29 ; 0.50$, and 0.23 panicles per $\mathrm{m}^{2} \mathrm{~kg}^{-1} \mathrm{~N}$ applied to BRS MG Curinga, BRS Monarca, BRS Pepita, BRS Primavera and BRS Sertaneja, respectively. In a comparison with results of Alvarez et al. (2002), no effect of $\mathrm{N}$ topdressing was observed for the number of panicles per $\mathrm{m}^{2}$ in rice cultivars, demonstrating that $\mathrm{N}$ response also depends on the cultivar, crop management, soil, and climate. The response to $\mathrm{N}$ topdressing can be attributed to the soil of the experimental area, which was deficient in organic matter, thus confirming the need for $\mathrm{N}$ topdressing.

The differentiated responses of the cultivars to $\mathrm{N}$ fertilization and timing of $\mathrm{N}$ application (Figure 2) may be closely linked to the genotype since, as stated by Fageria et al. (2006), panicle number is characteristic of the cultivar, but can be increased by applying appropriate $\mathrm{N}$ rates.

Panicle length was influenced by cultivar and $\mathrm{N}$ application times and rates (Table 1). When all $\mathrm{N}$ was applied at sowing (Figure $3 \mathrm{a}$ ), the response of BRS MG Curinga was linear, reaching a panicle length of $23.0 \mathrm{~cm}$ at the maximum rate applied. The response of the other cultivars BRS Monarca, BRS Primavera, BRS Pepita, and BRS Sertaneja to $\mathrm{N}$ rates was quadratic, reaching a panicle length of $25.8 ; 25.4 ; 24.0$, and $26.7 \mathrm{~cm}$, respectively, at $\mathrm{N}$ rates of 117 and $114 \mathrm{~kg}$ ha ${ }^{1}$ for BRS Monarca and BRS Primavera, and $150 \mathrm{~kg} \mathrm{ha}^{-1}$ for BRS Pepita and BRS Sertaneja, as similalry reported by Breseghello et al. (2006) for panicle length in cultivar BRS Sertaneja at a $\mathrm{N}$ rate of $80 \mathrm{~kg} \mathrm{ha}^{-1}$.

When applying $50 \%$ of $\mathrm{N}$ rates at sowing and $50 \%$ at tillering (Figure 3b), the response in panicle
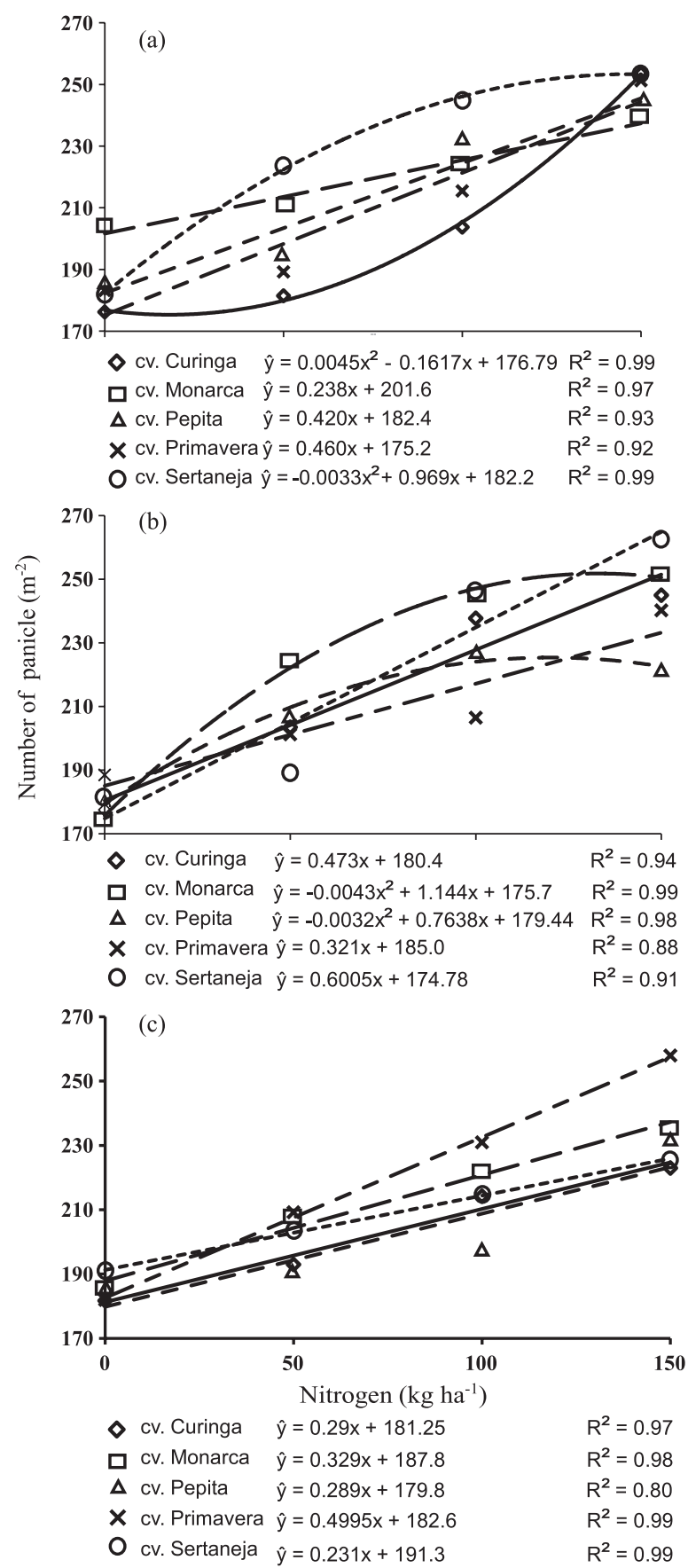

Figure 2. Number of panicles per $\mathrm{m}^{2}$ of cultivars as a function of $\mathrm{N}$ rates and application times $100 \%$ applied at planting (a); $50 \%$ at sowing and $50 \%$ at tillering (b); and $100 \%$ at tillering (c). 
length to $\mathrm{N}$ rates was linear, increasing by 4.0 ; 3.1 and $4.7 \mathrm{~cm}$ at $150 \mathrm{~kg} \mathrm{ha}^{-1} \mathrm{~N}$ in relation to rate zero in the cultivars BRS MG Curinga, BRS Pepita and BRS Sertaneja, respectively. The response of BRS Monarca and BRS Primavera was quadratic, reaching a maximum panicle length of 27.5 and $26.6 \mathrm{~cm}$ at 141 and $150 \mathrm{~kg} \mathrm{ha}^{-1} \mathrm{~N}$, respectively. The increase in panicle length was generally higher when $\mathrm{N}$ was applied at sowing only (Figure $3 \mathrm{a}$ ).
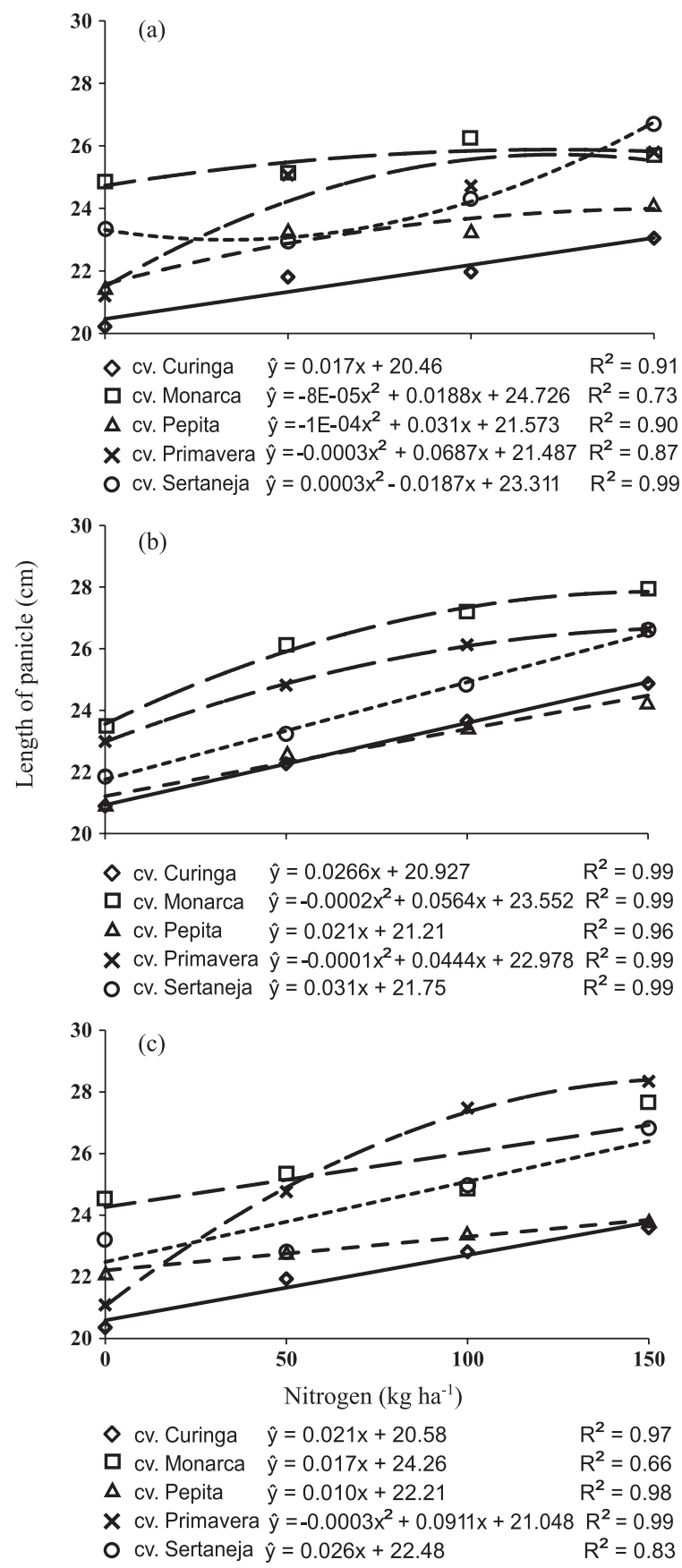

Figure 3. Panicle length of cultivars as a function of $\mathrm{N}$ rates and application time applied $100 \%$ at sowing (a); $50 \%$ at sowing and $50 \%$ at tillering (b); and $100 \%$ at tillering (c).
The response in panicle length of BRS Monarca, BRS Sertaneja, BRS MG Curinga, and BRS Pepita was linear when $100 \%$ of $\mathrm{N}$ was applied at tillering, with an increase of $2.5 ; 3.9 ; 3.1$ and $1.5 \mathrm{~cm}$ at $150 \mathrm{~kg} \mathrm{ha}^{-1} \mathrm{~N}$, compared to the zero rate, respectively (Figure 3c). However, the response of BRS Primavera to $\mathrm{N}$ rates was quadratic, reaching $27.9 \mathrm{~cm}$ of panicle length at $150 \mathrm{~kg} \mathrm{ha}^{-1} \mathrm{~N}$.

For the number of filled grains per panicle the interaction between cultivars and $\mathrm{N}$ rates was significant (Table 1). The response of BRS Primavera to $\mathrm{N}$ rates was linear when $100 \% \mathrm{~N}$ was applied at sowing (Figure 4a, and higher than all other cultivars with 156 spikelets at $150 \mathrm{~kg} \mathrm{ha}^{-1} \mathrm{~N}$, exceeding the treatment without $\mathrm{N}$ by $36.11 \%$. For BRS Monarca and BRS Sertaneja the number of filled grains increased linearly with increasing $\mathrm{N}$ doses at a rate of 0.20 and 0.26 filled grains $\mathrm{kg}^{-1} \mathrm{~N}$. The response to $\mathrm{N}$ rates of BRS Pepita was quadratic, with 133 spikelets in the treatment with $150 \mathrm{~kg} \mathrm{ha}^{-1}$ N. Cultivar BRS MG Curinga also responded to N increase in the number of spikelets per panicle, but less than the other cultivars, with only 125 filled grains at $98 \mathrm{~kg} \mathrm{ha}^{-1} \mathrm{~N}$. The results reinforce the importance of $\mathrm{N}$ as a key nutrient for rice in the panicle and grain formation (Barbosa Filho, 1987), stimulating root growth and, consequently, favoring tillering and increasing the number of spikelets per panicle (Husain \& Sharma, 1991).

The percentage of sterile spikelets per panicle was significantly affected by the interaction of cultivars and $\mathrm{N}$ rates (Table 1). Cultivars BRS MG Curinga and BRS Monarca responded linearly to $\mathrm{N}$ rates (Figure $4 \mathrm{~b}$ ), with 16.7 and $22.4 \%$ of sterile spikelets in the treatment with the highest $\mathrm{N}$ rate, respectively. BRS Pepita had a quadratic effect with increasing $\mathrm{N}$ rates, reaching $20.1 \%$ of sterile spikelets at $86 \mathrm{~kg} \mathrm{ha}^{-1} \mathrm{~N}$. The highest incidence of sterile spikelets was $26.8 \%$, in cultivar BRS Sertaneja, at $150 \mathrm{~kg} \mathrm{ha}^{-1} \mathrm{~N}$, while no significant effect was observed in BRS Primavera. The goal of decreasing the percentage of sterile spikelets per panicle at high $\mathrm{N}$ rates can be one of the challenges for the selection process in rice breeding, since other factors e.g., $\mathrm{N}$ excess, soil salinity and rice blast incidence also induce spikelet sterility (Yoshida $\&$ Parao, 1976). The low percentage of sterile spikelets per panicle observed in this study may be related to local soil and climatic conditions that did not favor the occurrence of rice blast, the disease generally responsible for increased spikelet sterility (Guimarães \& Prabhu, 2002); no water stress was stated in the plant reproductive phase, since under water stress the percentage of sterile spikelets per panicle reached $74 \%$ in BRS Primavera (Heinemann \& Stone, 2009).

The effect on 1000-grain mass was only significantly different among cultivars (Table 1), 

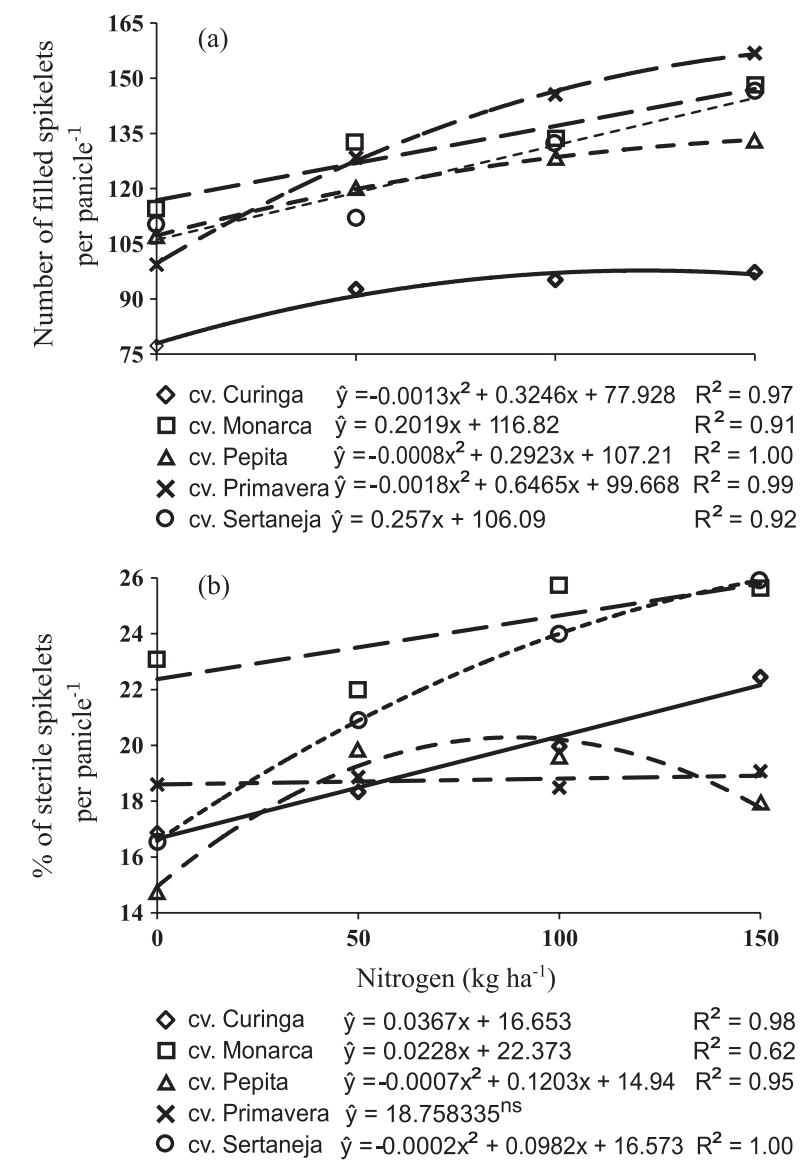

Figure 4. Number of filled grains per panicle (a) and percentage of sterile spikelets per panicle (b) of rice cultivars as a function of $\mathrm{N}$ rates.

since this yield component is stable and cultivarspecific, as reported by Yoshida (1981). The 1000-grain mass of BRS Monarca (Figure 5) was highest $(28.3 \mathrm{~g})$ and did not differ significantly from BRS Sertaneja (27.4 g) which, in turn, did not differ from BRS MG Curinga (26.9 g) and BRS Primavera $(26.3 \mathrm{~g})$. The 1000-grain mass of BRS Pepita was the lowest $(24.8 \mathrm{~g})$, statistically different from the others. The 1000-grain mass of all genotypes was higher than the values reported by Soares et al. (2001), Fonseca et al. (2004), Breseghello et al. (2006), Castro et al. (2007) and Breseghello et al. (2007), for the cultivars BRS Primavera, BRS MG Curinga, BRS Sertaneja, BRS Monarca, and BRS Pepita, respectively.

Grain yield was influenced by the cultivars, rates and timing of $\mathrm{N}$ application (Table 1). With application of $100 \% \mathrm{~N}$ at seeding, increasing $\mathrm{N}$ rates (Figure 6a) provided linear growth in yield of the BRS Primavera from 1,644 $\mathrm{kg} \mathrm{ha}^{-1}$, at zero rate, to $2,367 \mathrm{~kg} \mathrm{ha}^{-1}$ of grains, at $150 \mathrm{~kg} \mathrm{ha}^{-1} \mathrm{~N}$. For cultivars BRS MG Curinga and BRS Sertaneja, rice yield increased quadratically, reaching 1,778 and $3,493 \mathrm{~kg} \mathrm{ha}^{-1}$, respectively, at $150 \mathrm{~kg} \mathrm{ha}^{-1} \mathrm{~N}$.
BRS Monarca and BRS Pepita reached maximum yield of 2,721 and $2,730 \mathrm{~kg} \mathrm{ha}^{-1}$, at 132 and $91 \mathrm{~kg} \mathrm{ha}^{-1}$ $\mathrm{N}$, respectively. The difference in yields in response to $\mathrm{N}$ may be related to the interaction genotype $\mathrm{x}$ environment, since each variety has its peculiar characteristics (Brown \& Jones, 1997).

Higher $\mathrm{N}$ rates, applying $50 \%$ at sowing and $50 \%$ at tillering, resulted in linear grain yield increases (Figure 6b) of the cultivars BRS MG Curinga and BRS Primavera, from 808 and $1,740 \mathrm{~kg} \mathrm{ha}^{-1}$, without $\mathrm{N}$ application, to 2,055 and $4,440 \mathrm{~kg} \mathrm{ha}^{-1}$, at $150 \mathrm{~kg} \mathrm{ha}^{-1} \mathrm{~N}$. The yield of BRS Monarca and BRS Sertaneja increased in a quadratic form from 1,295 and $1,510 \mathrm{~kg} \mathrm{ha}^{-1}$ without $\mathrm{N}$ application, to 2,938 and $4,308 \mathrm{~kg} \mathrm{ha}^{-1}$ at $150 \mathrm{~kg} \mathrm{ha}^{-1} \mathrm{~N}$. Cultivar BRS Pepita reached a maximum yield of $2,221 \mathrm{~kg} \mathrm{ha}^{-1}$ at $91 \mathrm{~kg} \mathrm{ha}^{-1} \mathrm{~N}$. The cultivars which obtained yields above 4,000 kg ha-1 had increased 87 and $23 \%$, respectively, when compared to application of $100 \%$ of $\mathrm{N}$ at sowing (Figure 6a). This yield increase may have occurred because of the action of $\mathrm{N}$ in the rice development stage, contributing to tiller formation and number of panicles per area, where the split $\mathrm{N}$ rates efficiently induced yield increases (Cornélio et al., 2007).

When applying $100 \% \mathrm{~N}$ at tillering, BRS Sertaneja responded linearly to $\mathrm{N}$, increasing yield at a rate of $14.2 \mathrm{~kg}$ of grains per $\mathrm{kg}$ of $\mathrm{N}$ added, while BRS MG Curinga and BRS Pepita showed no significant responses to $\mathrm{N}$ application, not exceeding yields of 1,400 and $1,800 \mathrm{~kg} \mathrm{ha}^{-1}$, respectively (Figure 6c). The increasing $\mathrm{N}$ rates induced a quadratic response in grain yield of BRS Monarca and BRS Primavera. Cultivar BRS Monarca reached a maximum yield of $3,736 \mathrm{~kg} \mathrm{ha}^{-1}$, which is higher than that obtained with the other form of $\mathrm{N}$ application (Figure 6a,b) and the highest when compared to other cultivars at $100 \% \mathrm{~N}$ application at tillering. These results are possibly related to differences between cultivar responses to nitrogen fertilization and combinations of $\mathrm{N}$ rates and application times, as observed by Brown \& Jones (1997) that plant genotypes have different nutritional requirements.

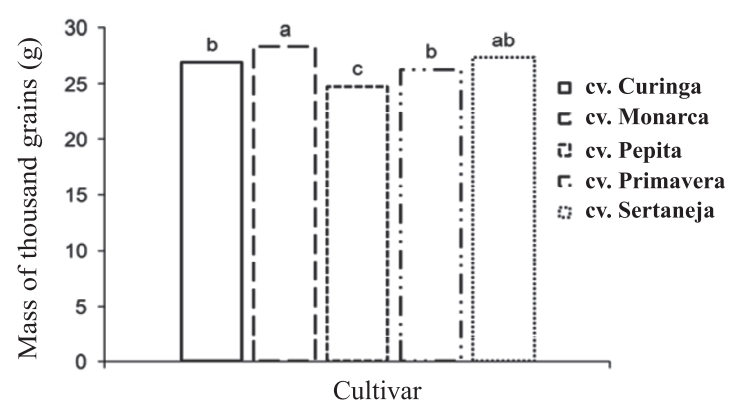

Figure 5. Mass of 1000 grains of rice cultivars. Means followed by the same letter do not differ by the Tukey test, at $5 \%$. 

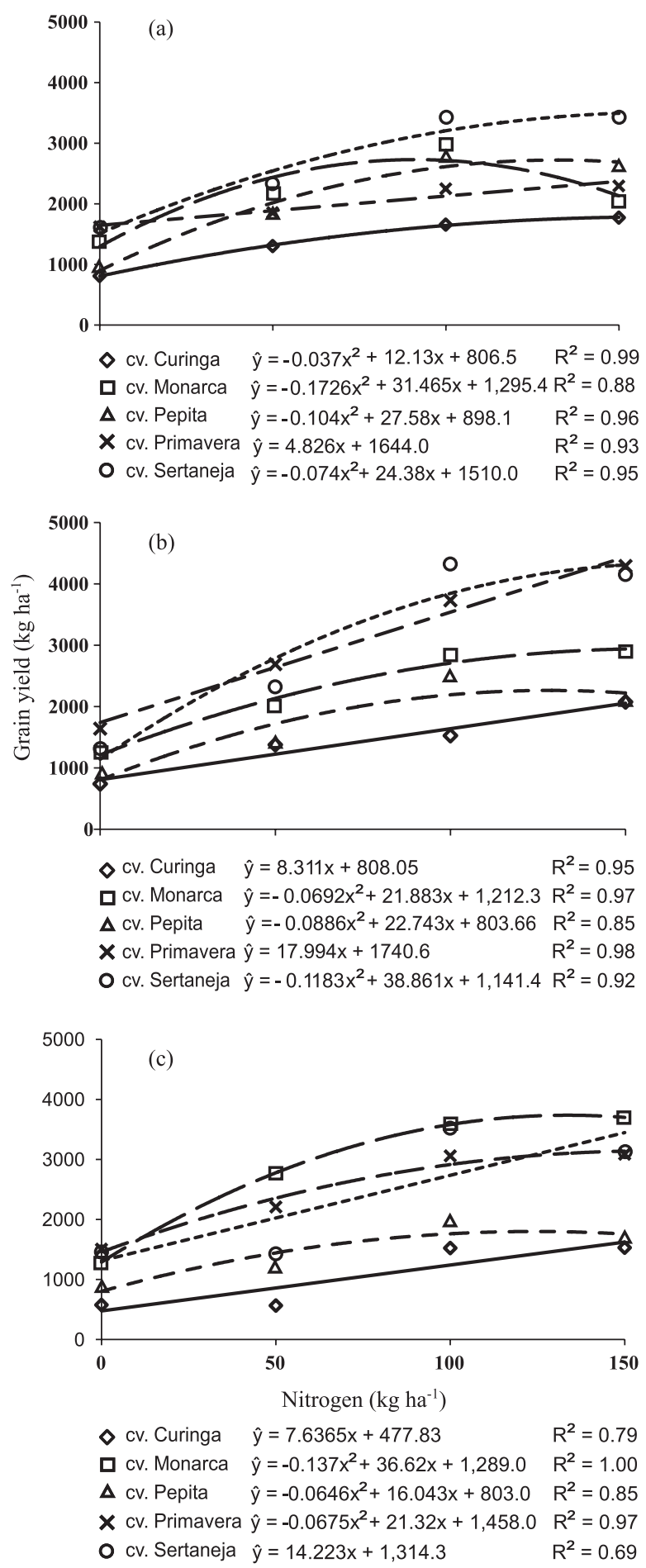

Figure 6. Grain yield of cultivars as a function of $\mathrm{N}$ rates and application times (a) $100 \%$ at planting; (b) $50 \%$ at sowing - $50 \%$ at tillering; and (c) $100 \%$ at tillering.

Correlating the number of panicles per $\mathrm{m}^{2}$ and the number of filled grains per panicle with grain yield, a linear yield increase was observed, with increases of $43.7 \mathrm{~kg} \mathrm{ha}^{-1}$ per panicle $\mathrm{m}^{-2}$ (Figure $7 \mathrm{a}$ ), and $70.7 \mathrm{~kg} \mathrm{ha}^{-1}$ per number of filled spikelets/ panicle (Figure 7b). It can be considered that the increase in grain yield is closely related to the number of panicles per $\mathrm{m}^{2}$ and the number of filled grains per panicle. The relationship between number of panicles per $\mathrm{m}^{2}$ and filled grains per panicle is important, since yields will only be satisfactory if there is balance between these two characteristics; increasing $\mathrm{N}$ rates can lead to a decrease in rice yields with fewer panicles per $\mathrm{m}^{2}$ (Husain \& Sharma, 1991).

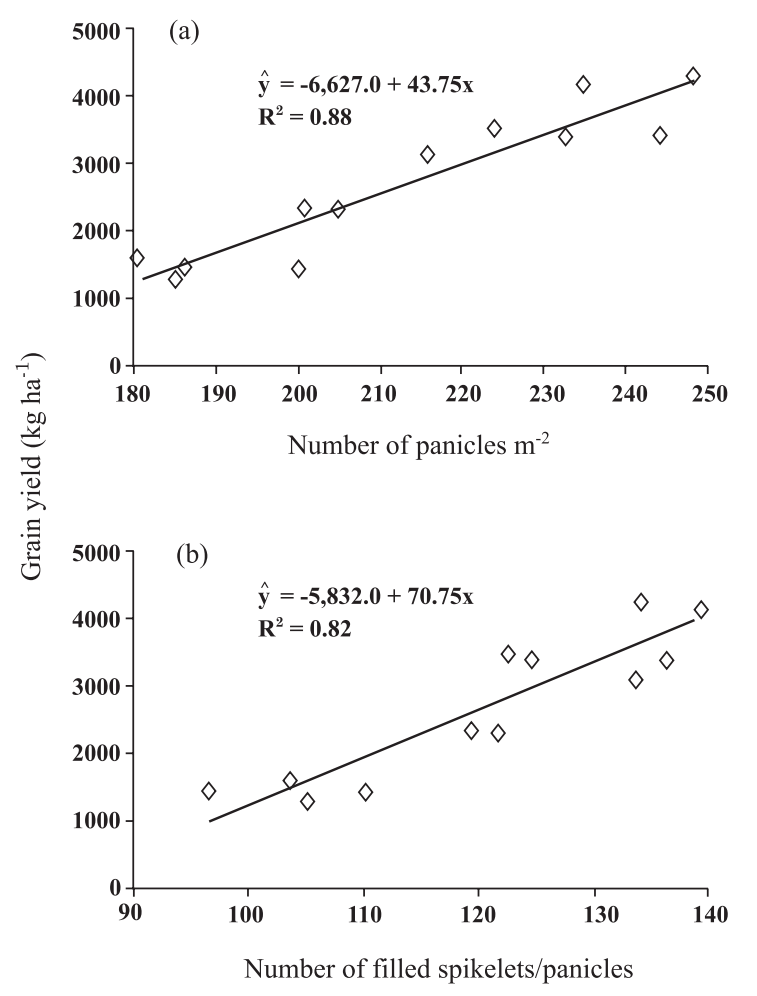

Figure 7. Grain yield as a function of the number of panicles $\mathrm{m}^{-2}$ (a) and number of filled grains per panicle (b).

\section{CONCLUSIONS}

1. The growth performance of the cultivars BRS Primavera and BRS Sertaneja was best, when $\mathrm{N}$ rates were split in two, $50 \%$ at sowing and $50 \%$ at tillering.

2. The response of cultivar BRS Monarca to $\mathrm{N}$ fertilization was best when all $\mathrm{N}$ was applied at tillering.

3. No significant response in grain yield was observed for the cultivars BRS MG Curinga and BRS Pepita, under the experimental climate and soil conditions.

4. The correlations of the yield components number of panicles per $\mathrm{m}^{2}$ and the number of filled grains per panicle with rice grain yield were the highest. 


\section{LITERATURE CITED}

ALVAREZ, A.C.C.; ARF, O.; PEREIRA, J.C.R. \& BUZETTI, S. Comportamento de cultivares de arroz (Oryza sativa L.) irrigado por aspersão em função da aplicação de diferentes doses de nitrogênio em cobertura. In: CONGRESSO DA CADEIA PRODUTIVA DE ARROZ, 1., Florianópolis, 2002. Anais... Florianópolis, 2002. p.526-529.

ANDRADE, W.E.B.; AMORIM NETO, S.; FERNANDES, G.M.B. \& OLIVEIRA, H.F. Épocas de aplicação de nitrogênio em cultivares de arroz irrigado na Região Norte Fluminense. Lav. Arroz., 45:14-17, 1992.

BARBOSA FILHO, M.P. Nutrição e adubação do arroz: Sequeiro e irrigado. Piracicaba, Associação Brasileira para Pesquisa da Potassa e do Fosfato, 1987. 129p.

BRESEGHELLO, F.O.; MORAIS, P.; CASTRO, E.M.; CASTRO, A.P.; UTUMI, M.M.; LOPES, A.M.; PEREIRA, J.A.; CORDEIRO, A.C.C.; SOARES, A.A.; BASSINELLO, P.Z.; FONSECA, J.R. \& PRABHU, A.S. BRS Pepita: Cultivar de arroz de terras altas produtiva e precoce. Santo Antônio de Goiás, Embrapa Arroz e Feijão, 2007. 4p. (Comunicado Técnico, 150)

BRESEGHELLO, F.O.; MORAIS, P.; CASTRO, E.M; PEREIRA, J.A.; UTUMI, M.M.; LOPES, I.M.; CORDEIRO, A.C.C.; BASSINELLO, P.Z.; FONSECA, J.R.; PRABHU, A.S.; PETERS, V. \& SOARES, A.A. BRS Sertaneja: cultivar precoce de arroz de terras altas. Santo Antônio de Goiás, Embrapa Arroz e Feijão, 2006. 4p. (Comunicado Técnico, 133)

BROWN, J.C. \& JONES, W.E. Fitting plant nutritionally to soil. Agr. J., 69:399-404, 1997.

CASTRO, A.P.; MORAIS, O.P.; CASTRO, E.M.; BRESEGHELLO, F.; LOPES, A.M.; UTUMI, M.M.; PEREIRA, J.A.; CORDEIRO, A.C.C.; LOBO, V.L.S.; SOARES, A.A.; SOUZA, N.R.G.; FONSECA, J.R.; BASSINELLO, P.Z.; GUIMARÃES, C.M.; KOAKUZU, S.N. \& PRABHU, A.S. BRS Monarca: Cultivar de arroz de terras altas com excelência em qualidade de grãos. Santo Antônio de Goiás, Embrapa Arroz e Feijão, 2007. 4p. (Comunicado Técnico, 148)

CORNÉLIO, V.M.O.; REIS, M.S.; SOARES, A.A.; SOARES, P.C. \& OLIVEIRA, J.A. Efeito de doses e épocas de aplicação de nitrogênio na incidência de doenças, produção e qualidade sanitária das sementes de arroz. Ci. Agrotec., 31:47-52, 2007.

EMPRESA BRASILEIRA DE PESQUISA AGROPECUÁRIA EMBRAPA. Centro Nacional de Pesquisa de Solos. Manual de métodos de análise de solo. 2.ed. Rio de Janeiro, 1997. 212 .

EMPRESA BRASILEIRA DE PESQUISA AGROPECUÁRIA EMBRAPA. Centro Nacional de Pesquisa de Solos. Sistema brasileiro de classificação de solos. 2.ed. Rio de Janeiro, 2006. 306p
FAGERIA, N.K. Growth and mineral nutrition of field crops. 2.ed. New York, 1997. 624p.

FAGERIA, N.K. \& SANTOS, A.B.D. EMBRAPA: Cultivo do Arroz Irrigado no Estado do Tocantins. Available at: <http:// sistemasdeproducao.cnptia.embrapa.br/FontesHTML/ Arroz/Arro zIrrigadoTocantins/adubacao_calagem. htm\#nitrogenio>. Accessed 14 May, 2010.

FAGERIA, N.K.; BALIGAR, V.C. \& CLARK, R.B. Physiology of crop production. New York, 2006. 345p.

FAGERIA, N.K. \& BARBOSA FILHO, M.P. Avaliação preliminar de cultivares de arroz irrigado para maior eficiência de utilização de nitrogênio. Pesq. Agropec. Bras., 17:17091712,1982

FAGERIA, N.K.; SLATON, N.A. \& BALIGAR, V.C. Nutrient management for improving lowland rice productivity and sustainability. Adv. Agron., 80:63-152, 2003.

FARINELLI, R.; PENARIOL, F.G.; FORNASIERI FILHO, D. \& BORDIN, L. Características agronômicas de arroz de terras altas sob plantio direto e adubação nitrogenada e potássica. R. Bras. Ci. Solo, 28:447-454, 2004.

FONSECA, J.R.; CASTRO, E.M.; MORAIS, O.P. \& ZIMMERMANN, F.J.P. Pontos de colheita e características das cultivares de arroz de terras altas "BRSMG Curinga" e "BRS Liderança". Santo Antônio de Goiás, Embrapa Arroz e Feijão, 2004. 4p. (Comunicado Técnico, 79)

GUIMARÃES, C.M. \& PRABHU, A.S. Adubação orgânica no arroz de terras altas: relacionamentos entre brusone, esterilidade de espiguetas e produtividade. Santo Antônio de Goiás, Embrapa Arroz e Feijão, 2002. 2p. (Comunicado Técnico, 42)

HEINEMANN, A.B. \& STONE, L.F. Efeito da deficiência hídrica no desenvolvimento e rendimento de quatro cultivares de arroz de terras altas. Pesq. Agropec. Trop., 39:134-139, 2009.

HUSAIN, S.M. \& SHARMA, U.C. Response of rice to nitrogen fertilizer in acidic soil of Nagaland. J. Agric. Sci., 61:662664,1991

MARZARI, V. Influência da população de plantas, doses de nitrogênio e controle de doenças na produção e qualidade de grãos e sementes de arroz irrigado. Santa Maria, Universidade Federal de Santa Maria, 2005. 63p. (Tese de Mestrado)

MAUAD, M.; GRASSI FILHO, H.; CRUSCIOL, C.A.C. \& CORREAA, J.C. Teores de silício no solo e na planta de arroz de terras altas com diferentes doses de adubação silicatada e nitrogenada. R. Bras. Ci. Solo, 27:867-873, 2003.

PRABHU, A.S.; FARIA, J.C. \& CARVALHO, J.R.P. Efeito da brusone sobre a matéria seca, produção de grãos e seus componentes, em arroz de sequeiro. Pesq. Agropec. Bras., 21:495-500, 1986. 
SOARES, A.A.; CORNÉLIO, V.M.O.; SOARES, P.C.; SANTOS, P.G. \& REIS, M.S. Primavera: Cultivar de arroz com grãos agulhinha para cultivo em terras altas. R. Ceres., 48:381$388,2001$.

YOSHIDA, S. Fundamentals of rice crop science. Los Baños, 1981. 269p.
YOSHIDA, S. \& PARAO, F.T. Climatic influence on yield and yield components of lowland rice in the tropics. Clim. Rice, 471-494, 1976. 
